\title{
Role of matrix metalloproteinase 9 and its tissue inhibitor 1 in development and prognosis of diabetic retinopathy
}

\author{
S.V. Ziablitsev ${ }^{1}$, A.V. Korobova ${ }^{2}$, O.V. Petrenko ${ }^{3}$, V.N. Serduk ${ }^{4}$, S.U. Mogilevsky ${ }^{3}$ \\ ${ }^{1}$ Ukranian science-practical center of endocrine surgery, transplantation of endocrine organs and tis- \\ sue Health Ministry of Ukraine, Kyiv; ${ }^{2}$ M. Gorky Donetsk National Medical University, Krasny Liman; \\ ${ }^{3}$ L.M. Shupik National medical academy of postgradual education, Kyiv; ${ }^{4}$ SE «Dnepropetrovsk Medical \\ Academy Health Ministry of Ukraine»,Dnipro; e-mail: zsv1965@gmail.com
}

The article presents the results of investigation of violations in the proteolysis system in patients with type 2 diabetes and diabetic retinopathy (DR). We studied the levels of matrix metalloproteinase-9 (MMP-9) and tissue inhibitor of matrix metalloproteinase-1 (TIMP-1) in the blood and in the intraocular fluid of patients with type 2 diabetes depending upon the stage of DR. We have established that the level of MMP-9 and TIMP-1 in the blood and in the intraocular fluid increased in patients with type 2 diabetes without signs of $D R$ and with any stage of $D R$ compared to the levels of these parameters in patients without diabetes. Increasing the levels of MMP-9 and TIMP-1 took place with increasing of DR severity and reached its maximum levels at the proliferative stage of DR. It was found that the levels of MMP-9 in the intraocular fluid and type 2 diabetes duration affected the probability of developing diabetic macular edema. At the level of $M M P-9 \geq 105 \mathrm{ng} / \mathrm{ml}$ and 2 diabetes duration $\geq 10$ years, the probability of developing macular edema was $100 \%$. As a result of the construction of predictive models it was found that the level of MMP-9 in the intraocular fluid, stage of $D R$ at the beginning of observation and type 2 diabetes duration had influence on the probability of the development of proliferative DR over 4 years of follow-up. If the level of MMP-9 $\geq 100 \mathrm{ng} / \mathrm{ml}$, type 2 diabetes duration $\geq 10$ years and absence of $D R$ at the beginning of observation were observed the probability of developing proliferative DR would compose $85.9 \%$.

Key words: proteolysis system; metalloproteinase-9; tissue inhibitor of matrix metalloproteinase-1; intraocular fluid; diabetic retinopathy.

\section{INTRODUCTION}

In recent years the proteolysis system which includes matrix metalloproteinases (MMPs) and tissue inhibitors of matrix metalloproteinases (TIMP) is in increasing interest when studying chronic inflammatory processes, cardiovascular, autoimmune and neoplastic diseases [1, 2]. MMPs are a family of secreted or membranetype, zinc- or calcium-dependent proteolytic enzymes which are essential in embryogenesis, morphogenesis and tissue remodeling [2-4]. Increasing evidences suggest an important role of MMP-9 in pathogenesis of myocardial infarction, rheumatoid arthritis, cancer, obstructive lung diseases, multiple sclerosis, hepatitis and liver cirrhosis, as well as in development of such complication of diabetes mellitus (DM) as diabetic retinopathy (DR) [5-9].

MMP-9 is a zinc-containing MMP with gelatinase activity and its substrates include collagens IV, V, VII, X, XIV, fibrin, gelatin, fibronectin, elastin, vitronectin, proteoglycanbinding protein, entactin, osteonectin, chondroitin sulfate. Retinal extracellular matrix has an ordered structure and vascular basement membrane comprises collagen IV, fibronectin, laminin vitronektin $[7,10]$. There are several types of cells including endotheliocytes, basophils, neutrophils, smooth muscle cells and activated macrophages which secrete MMP-9 under the (C) S.V. Ziablitsev, A.V. Korobova, O.V. Petrenko, V.N. Serduk, S.U. Mogilevsky 
influence of proinflammatory cytokines and other factors [11].

DR is a major cause of blindness among working-age people suffering from DM [12, 13]. According to Health Ministry of Ukraine data the prevalence of DM in our country is $2.5 \%$. However according to International Diabetes Federation data it was 2009 when the prevalence of DM in Ukraine has already been $9.6 \%$ with $92 \%$ of patients with DM type 2 [14, 15]. Worldwide, the number of people with DR will increase from 126.6 million in 2010 to 191 million by 2030 [12]. DR leads to a decrease in visual function in $30-90 \%$ of diabetic patients $[13,16]$. Although DR has traditionally been considered a late complication of diabetes, it can justifiably be regarded as a typical pathological change in retinal vascular bed [17]. In recent years an efficiency of metabolic control and blood pressure control in protection of DR progression has been proven. However in our country only $13.1 \%$ of patients achieved target levels of glycosylated hemoglobin (HbA1c) $<7 \%$ in 2014 [18]. The earliest preclinical signs of DR include selective apoptosis of pericytes, Müller cells, glial cells and endotheliocytes, as well as an increase in mitochondrial damage. However, the precise pathophysiological mechanism of retinal vascular bed cells death in the DR is still unclear [8, 10, 11, 19]. The greatest threats for blindness development in patients with DM type 2 are diabetic macular edema (DME) and proliferative diabetic retinopathy (PDR) [16, 17, 20].

Based on the above reasons, the goal of our study was to investigate the role of disturbances in the proteolysis system (MMP-9 and TIMP-1) in the development and progression of DR.

\section{METHODS}

MMP-9 and TIMP-1 levels were determined in the blood and intraocular fluid (IOF) of 154 patients (163 eyes), of which 112 patients (121 eyes) had DM type 2 (the study group) and 42 patients (42 eyes) were not diabetic (the control group). All patients were subjected to surgery for age-related cataract by means of phacoemulsification with further intraocular lens implantation. The patients' mean age was $67.55 \pm 0.83$ years in the study group and $67.09 \pm 1.49$ years in the control group $(\mathrm{P}=0.84)$. There were $62.5 \%$ female and $37.5 \%$ male patients in the study group and $59.5 \%$ female and $40.5 \%$ male patients in the control group, respectively $(\mathrm{P}=0.73)$. DM type 2 mean duration in the study group was $6.07 \pm 0.31$ years (minimal -0.5 year; maximal -18 years) Patients receiving statins and fibrates and those who had renal failure, pancreatitis, neoplastic diseases, obstructive respiratory diseases, prior myocardial infarction, glaucoma, age-related macular degeneration, intravitreal injections of medications and laser coagulation of the retina in history were excluded. The study group patients with $\mathrm{HbA} 1 \mathrm{c}>8.0 \%$ were also excluded. Written informed consent on blood and IOF sampling for determining of MMP-9 and TIMP-1 levels and the use of research results for scientific purposes was obtained from each patient. MMP-9 and TIMP-1 levels in patients' blood and IOF were determined on the ELISA analyzer «PR2100 Sanofi diagnostic Pasteur» (France) by means of kits for ELISA "matrix metalloproteinase-9" and "tissue inhibitor of matrix metalloproteinase-1" produced by Bender Medsystems (Austria) according to the instructions of the manufacturer. Follow-up in the study group was 4 years with ophthalmologic examination of patients each 6 months. The degree of DR severity in patients with DM type 2 was determined after cataract surgery using a DR severity scale of the American Academy of Ophthalmology [21]. Ophthalmologic examination included visometry, refractometry, pneumotonometry, biomicroscopy, contact retinal biomicroscopy with Goldmann lens. Optical coherence tomography on the tomograph Stratus OCT, Carl Zeiss (Germany), color photography of ocular fundus on Visucam Zeiss apparatus; fluorescent retinal angiography if indicated, were also carried out. The final 
assessment of the retina state in the study group was performed at the beginning of follow-up after surgery, as well as at the end of the 1-st and 4-th year of observation.

For statistical analysis Statistica 7.0 (StatSoft Inc., 2004) were used. Quantitative variables were expressed as $\mathrm{M} \pm \mathrm{m}$ where $\mathrm{M}$ - mean value, $\mathrm{m}$ - standard deviation, median Me - median. Cause-effect relationships and the role of prognostic risk factors in DME development in patients with DM type 2 during 1-st year of follow-up were investigated. A mathematical model for predicting DME development was based on the results of observations of 121 eyes in the study group. A mathematical model to predict PRD development was based on the results of observations of 112 eyes in the study group (as patients with signs of PRD at the beginning of observations were excluded). Prognostic risk factors include MMP-9 levels in IOF, sex, age, DM duration and a degree of DR at the beginning of observations (it was estimated by scale from 0 to 3 , where $0-$ no DR 1 - initial nonproliferative DR (NPDR), 2 - moderate NPDR, 3 - severe NPDR).

A probability of the event (DME or PRD development) ranging from 0 to 1 was predicted using binary logistic regression. There was no probability of the event if $\mathrm{P}=0-0.5$ (i.e. less than 50\%). Otherwise there was more than $50 \%$ probability the event to occur if $\mathrm{P}>0.5$.

\section{RESULTS AND DISCUSSION}

It was established that after cataract surgery in the study group there were $51.2 \%$ cases $(62$ eyes) with no DR, $16.5 \%$ cases (20 eyes) of initial NPDR, $18.2 \%$ cases ( 22 eyes) of moderate NPDR, $6.6 \%$ cases ( 8 eyes) of severe NPDR and $7.5 \%$ cases ( 9 eyes) of PDR.

Mean blood MMP-9 and TIMP-1 levels in patients of the study group were increased compared to those in the control group (table 1).

Blood MMP-9 levels in patients with DM type 2 having different stages of DR ranged from $55.89 \mathrm{ng} / \mathrm{ml}$ to $124.65 \mathrm{ng} / \mathrm{ml}$, while in nondiabetic patients a minimal blood level of MMP-9 was $30.89 \mathrm{ng} / \mathrm{ml}$, and maximal $-80.00 \mathrm{ng} / \mathrm{ml}$.

Minimal blood TIMP-1 level in patients of the study group was $239.34 \mathrm{ng} / \mathrm{ml}$, and maximal $-496.50 \mathrm{ng} / \mathrm{ml}$, while in the control group minimal blood TIMP-1 level was $127.58 \mathrm{ng} /$ $\mathrm{ml}$, and maximal - $433.90 \mathrm{ng} / \mathrm{ml}$, respectively.

Our data on an increase in blood MMP-9 and TIMP-1 levels in patients with DM type 2 are consistent with the results obtained by foreign researchers $[9,22]$. However in Tayebjee M.H. et al. study there was not a statistically significant difference in MMP-9 levels between patients with DM type 2 and the control group [22]. This perhaps could be explained by the presents in the aforementioned study of patients with concomitant somatic pathology which may affect MMP-9 levels. According to Derosa G. et al. study plasma levels of MMP-9, TIMP-1 and TIMP-2 are increased in diabetic patients compared to nondiabetic individuals, that could reflect pathological changes in extracellular matrix remodeling at this disease [9]. In our opinion, an increase in blood MMP-9 and TIMP1 levels in patients with DM type 2 suggests that in patients with DM type 2 and DR there is a systemic involvement of body vessels in chronic immune inflammation and accelerated

Table 1. Blood MMP-9 and TIMP-1 levels in patients of the study and control groups (M \pm m; Me; min; max)

\begin{tabular}{l|c|c|c|}
\hline Indexes & $\begin{array}{c}\text { The study group } \\
(\mathrm{n}=112)\end{array}$ & $\begin{array}{c}\text { The control group } \\
(\mathrm{n}=42)\end{array}$ & $\begin{array}{c}\text { Statistical } \\
\text { significance. } \mathrm{P}\end{array}$ \\
\hline MMP-9 $\mathrm{ng} / \mathrm{ml} \mathrm{Me} ;$ & $79.37 \pm 1.45$ & $51.28 \pm 1.7$ & $\mathrm{P}<0.001$ \\
$\min ; \max$ & $77.12 ; 55.89 ; 124.65$ & $50.0 ; 30.89 ; 80.00$ & \\
TIMP-1 $\mathrm{ng} / \mathrm{ml}$ & $339.87 \pm 5.56$ & $218.44 \pm 11.81$ & $\mathrm{P}<0.001$ \\
Me; $\min ; \max$ & $326.06 ; 239.34 ; 496.50$ & $189.86 ; 127.58 ; 433.90$ & \\
\hline
\end{tabular}


atherosclerosis as DM type 2 is an equivalent of coronary heart disease [23]. Furthermore, MMP-9 is considered as a marker of systemic inflammation and as a marker of atheromatous plaque destabilization [23].

It was found that blood MMP-9 levels in patients with DM type 2 increased in accordance with the severity of retinal lesions (table 2).

In the study group, even in the absence of DR, blood MMP-9 levels exceeded those in the control group $(\mathrm{P}<0.001)$. The highest blood MMP-9 levels were revealed in patients with PDR - 103.34 \pm 6.14 ng/ml. Blood TIMP-1 levels in patients of the study group in the absence of DR and at any stage of DR were higher than those in the control group $(\mathrm{P}<0.05)$. The highest blood TIMP-1 levels were revealed in patients with PDR - 436.06 $\pm 23.49 \mathrm{ng} / \mathrm{ml}$.

In Beránek M. et al. study (2010) elevated blood MMP-9 levels were indentified in patients with DM and PDR as well as in patients with DM type 2 and not PDR compared to the control group [24]. In general, our results were consistent with the data of that study.

In our study it was found that mean MMP9 and TIMP-1 levels in IOF are increased in patients with DM type 2 compared to those in patients of the control group $(\mathrm{P}<0.001)$ (table 3$)$.

Table 4 shows MMP-9 and TIMP-1 levels in IOF of patients with DM type 2 according to the stage of DR, as well as a comparison of these variables between groups of patients without DR, with initial, moderate and severe NPDR and PDR and with the control group. It was found that MMP-9 and TIMP-1 levels in IOF of patients of the study group are increased at any stage of DR and in those having no DR as compared to patients of the control group $(\mathrm{P}<0.05)$. The levels of MMP-9 and TIMP-1 increased in accordance with the severity of DR and peaked at the proliferative stage of the disease $-117.78 \pm 6.35 \mathrm{ng} / \mathrm{ml}$ and $512.13 \pm 19.26$ $\mathrm{ng} / \mathrm{ml}$, respectively (table 4).

Abu El-Asrar A.M. et al. (2013) by means of Western blot and zymography analysis demonstrated significant increases in the expression levels of MMP-1, MMP-7, MMP-9 and vascular endothelial growth factor (VEGF) in vitreous samples from 32 PDR patients compared to nondiabetic controls [25]. In that study it was also shown an increase in the expression of MMP-9 by vascular endothelial cells and stromal cells in fibrovascular epiretinal membranes in PDR. In epiretinal membranes of patients with PDR cytoplasmic immunoreactivity for MMP-9 was present in vascular endothelial cells, monocytes, macrophages and neutrophils. These findings suggested that intraocular cellular production is the relevant source of MMP-9 and VEGF and that systemic inflow mechanism is

Table 2. Blood MMP-9 and TIMP-1 levels in patients of the study group depending on DR stage (M \pm m)

\begin{tabular}{lcc|}
\hline DR stage & MMP-9 $(\mathrm{ng} / \mathrm{ml})$ & TIMP-1 (ng/ml) \\
\hline An absence of DR $(\mathrm{n}=54)$ & $70.59 \pm 1.15 *$ & $310.65 \pm 5.39 *$ \\
Initial NPDR $(\mathrm{n}=19)$ & $77.61 \pm 1.31 * \#$ & $330.25 \pm 6.81 * \#$ \\
Moderate NPDR $(\mathrm{n}=22)$ & $84.55 \pm 2.0 * \#$ & $349.88 \pm 7.23 * \#$ \\
Severe NPDR $(\mathrm{n}=8)$ & $97.46 \pm 8.02 * \#$ & $408.59 \pm 25.02 * \#$ \\
PDR (n=9) & $103.34 \pm 6.14 * \#$ & $436.06 \pm 23.49 *$ \\
* difference in comparison with the control group is statistically significant, P<0.05; \\
\# difference in comparison of similar indexes levels between the different stages of DR (between an absence \\
DR and initial NPDR; between initial NPDR and moderate NPDR; between moderate NPDR and severe \\
NPDR; between severe NPDR and PDR), P<0.05.
\end{tabular}


Table 3. MMP-9 and TIMP-1 levels in IOF from patients of the study and control groups (M $\pm \mathrm{m}$; Me; min; max)

\begin{tabular}{l|cc|c|}
\hline Indexes & The study group $(\mathrm{n}=121)$ & The control group $(\mathrm{n}=42)$ & $\begin{array}{c}\text { Statistical } \\
\text { significance P }\end{array}$ \\
\hline MMP-9 $\mathrm{ng} / \mathrm{ml} \mathrm{Me} ;$ & $85.97 \pm 1.57$ & $46.92 \pm 2.35$ & $\mathrm{P}<0.001$ \\
min; max & $82.1 ; 55.35 ; 146.52$ & $43.15 ; 22.45 ; 87.05$ & \\
TIMP-1 $\mathrm{ng} / \mathrm{ml}$ & $397.63 \pm 7.33$ & $231.36 \pm 16.44$ & $\mathrm{P}<0.001$ \\
Me; min; $\max$ & $366.05 ; 256.18 ; 680.87$ & $191.29 ; 132.55 ; 650.76$ & \\
\hline
\end{tabular}

rather improbable. The authors concluded that it was MMP-1 and MMP-9 contributed to the retinal neoangiogenesis and fibrosis resulting in PDR development.

Our findings of increased levels of MMP-9 in IOF in initial stages of NPDR and in PDA are consistent with the views of foreign authors on the dual role of MMP-9 in DR development: in early stages of the disease MMP-9 promotes retinal capillary cell death and increased permeability of the inner blood-retinal barrier, and later, in the proliferative stage, it is involved in processes of retinal neovascularization [19].

TIMP-1 levels were significantly increased in the vitreous of diabetic patients with the highest levels in PDR patients. In that study a strong correlation between TIMP-1 expression and proMMP-9 in vitreous of patients with PDR was also found. Demonstrated that human diabetic neovascular membranes contain high levels of type IV collagenases which include MMP-9 and
MMP-2, while active forms of these enzymes are not found in the normal human retina.

According to the results of calculations the final prognostic model for DME development within $1^{\text {st }}$ year of follow-up in patients with DM type 2 includes two features: levels of MMP-9 in IOF and DM type 2 duration. In general form the equation for the binary logistic regression is as follows:

$$
P=\frac{1}{1-2.718^{-9.951+\left(-0.112 \times X_{1}-0.266 \times X_{2}\right)}},
$$

where $X_{1}$ - MMP-9 levels in IOF (ng/ml), $X_{2}$ DM type 2 duration (years).

It was found that at MMP-9 levels $\geq 105 \mathrm{ng} /$ $\mathrm{ml}$ and DM type 2 duration $\geq 10$ years the probability for DME development within 1-st year follow-up is $100 \%(\mathrm{P}=1)$. At MMP-9 levels = $90 \mathrm{ng} / \mathrm{ml}$ and DM type 2 duration $=5$ years the probability for DME development within 1-st year follow-up is still high $81 \%(\mathrm{P}=0.81)$.

Table 4. MMP-9 and TIMP-1 levels in IOF from patients of the study group depending on DR stage (M \pm m)

\begin{tabular}{lcc|}
\hline DR stage & MMP-9 $(\mathrm{ng} / \mathrm{ml})$ & TIMP-1 (ng/ml) \\
\hline An absence of DR $(\mathrm{n}=62)$ & $76.32 \pm 1.51 *$ & $362.86 \pm 8.45 *$ \\
Initial NPDR $(\mathrm{n}=20)$ & $81.54 \pm 1.61 * \#$ & $391.38 \pm 14.74 * \#$ \\
Moderate NPDR $(\mathrm{n}=22)$ & $96.67 \pm 1.8 * \#$ & $433.57 \pm 16.12 * \#$ \\
Severe NPDR $(\mathrm{n}=8)$ & $109.376 \pm 4.39 * \#$ & $464.90 \pm 22.36 * \#$ \\
PDR (n=9) & $117.78 \pm 6.35 * \#$ & $512.13 \pm 19.26 *$ \\
\hline
\end{tabular}

* difference in comparison with the control group is statistically significant, $\mathrm{P}<0.05$;

\# difference in comparison of similar indexes levels between the different stages of DR (between an absence DR and initial NPDR; between initial NPDR and moderate NPDR; between moderate NPDR and severe NPDR; between severe NPDR and PDR), $\mathrm{P}<0.05$. 
In our study DME developed within 1-st year of follow-up in 28 eyes (23.14\% of cases) of which 8 eyes did not have signs of DR at the beginning of observation, 2 eyes had signs of initial NPDR, 14 eyes - moderate NPDR and 4 eyes - PRD. The presence of DME was confirmed by examination data, optical coherence tomography and FAG of the retina. These patients required laser treatment and/or intravitreal VEGF inhibitors. Of 28 eyes with DME in 26 eyes $(92.7 \%)$ MMP-9 levels in IOF were above $90 \mathrm{ng} / \mathrm{ml}$.

Within 4-year follow-up PDR developed in $19.64 \%$ of cases (22 of 112 eyes in patients of the study group) and it was accompanied by occurrence of a large number of hard and cotton-like exudates, an increase in number of microhemorrhages and occurrence of large intraretinal and preretinal hemorrhages, optic disc neovascularization and retinal neovascularization. PDR development was confirmed by examination data and FAG of the retina. These patients required laser treatment, vitreoretinal surgery and intravitreal VEGF inhibitors. The mean MMP-9 level in IOF in these patients was $102.37 \pm 2.72 \mathrm{ng} / \mathrm{ml}$, TIMP-1 - 495.67 $\pm 21,85 \mathrm{ng} /$ $\mathrm{ml}$, DM type 2 duration $-9.41 \pm 0.08$ years.

Within 4-year follow-up DR occurred and progressed in 45 eyes ( $37.19 \%$ of cases): in 28 eyes DME has developed, in 22 eyes PDR has developed and in 8 eyes without DR signs of moderate NPDR have developed.

According to the results of calculations the final prognostic model for PDR development within 4-year follow-up in patients with DM type 2 includes three features: a stage of DR at the beginning of observation, levels of MMP-9 in IOF and DM type 2 duration. The equation for the binary logistic regression is as follows:

$$
P=\frac{1}{1-2.718^{-16.665+\left(-0.125 \times X_{1}-0.594 \times X_{2}-0.338 \times X_{3}\right)}},
$$

where $X_{1}-$ MMP-9 levels in IOF (ng/ml), $X_{2}-$ DM type 2 duration (years), $X_{3}$ - a stage of DR at the beginning of observation.

It was found that at MMP-9 level $\geq 105 \mathrm{ng} /$ $\mathrm{ml}$ and DM type 2 duration $\geq 10$ years and an absence of DR at the beginning of observation the probability for PDR development within 4-year follow-up is high and accounts $85.9 \%$ $(\mathrm{P}=0.859)$.

Thus, MMP-9 levels in IOF of patients with DM type 2, the initial degree of DR severity as well as DM type 2 duration were statistically significant risk factors for DR progression within 4 years of follow-up.

\section{CONCLUSIONS}

Alterations in the proteolysis system in patients with DR and DM type 2 were revealed. They included an increase in MMP-9 and TIMP-1 levels in blood and IOF in patients with DM and the absence of signs of DR and in patients with DM and DR of any stage compared to those in nondiabetic patients $(\mathrm{P}<0.05)$. MMP-9 and TIMP-1 levels increased in accordance to an increase in DR severity: MMP-9, TIMP-1 levels reached a maximum in PDR $(103.34 \pm 6.14 \mathrm{ng} /$ $\mathrm{ml}$ and $436.06 \pm 23.49 \mathrm{ng} / \mathrm{ml}$ in blood and $117.78 \pm 6.35 \mathrm{ng} / \mathrm{ml}$ and $512.13 \pm 19.26 \mathrm{ng} / \mathrm{ml} \mathrm{in}$ IOF, respectively).

By means of prognostic model constructing it was established that MMP-9 levels in IOF and DM type 2 duration have an effect on the probability for DME development. At MMP-9 levels $\geq 105 \mathrm{ng} / \mathrm{ml}$ and DM type 2 duration $\geq 10$ years the probability for DME development within 1 -year follow-up is 100\%. At MMP-9 levels $90 \mathrm{ng} / \mathrm{ml}$ and DM type 2 duration 5 years the probability for DME development within 1-year follow-up is $81 \%$.

By means of prognostic model constructing it was established that MMP-9 levels in IOF, a stage of DR at the beginning of observation and DM type 2 duration have an effect on the probability for PDR development in patients with DM type 2 within 4-year follow-up. At MMP-9 levels $\geq$ $105 \mathrm{ng} / \mathrm{ml}$, DM type 2 duration $\geq 10$ years and an absence of DR at the beginning of observation the probability for PDR development within 4-year follow-up is high and accounts $85.9 \%$ $(\mathrm{P}=0.859)$. 
С.В. Зябліцев ${ }^{1}$, О.В. Коробова ${ }^{2}$, О.В. Петренко ${ }^{3}$, В.М. Сердюк ${ }^{4}$, С.Ю. Могилевський ${ }^{3}$

\section{РОЛЬ МАТРИКСНОЇ МЕТАЛОПРОТЕЇНАЗИ 9 ТА ÏÏ ТКАНИННОГО ІНГІБІТОРА 1 В РОЗ- ВИТКУ І ПРОГНОЗУВАННІ ДІАБЕТИЧНОЇ РЕТИНОПАТІї}

У статті наведено результати дослідження порушень у системі протеолізу у хворих на цукровий діабет (ЦД) 2-го типу та діабетичну ретинопатію (ДР). Вивчали вміст матриксної металопротеїнази 9 (ММП-9) і ії тканинного інгібітора 1 (ТІМП-1) у крові та внутрішньоочній рідині (ВОР) хворих на ЦД 2-го типу залежно від стадії ДР. Встановлено зміни в системі протеолізу у хворих на ДР і ЦД 2-го типу, які полягали в підвищенні вмісту ММП-9 і ТІМП-1 у крові та ВОР як за відсутності ознак ДР, так і за будь-якої її стадії порівняно з цими показниками у хворих без діабету. Підвищення вмісту ММП-9 і ТІМП1 у крові та ВОР хворих на ЦД 2-го типу відбувалося зі збільшенням тяжкості ДР: за проліферативної ДР ці показники досягли максимуму. Встановлено, що вміст ММП-9 у ВОР і тривалість ЦД 2-го типу впливають на ймовірність розвитку діабетичного макулярного набряку. За вмісту ММП-9 $\geq 105$ нг/мл і тривалості ЦД 2-го типу понад 10 років вона становить $100 \%$. У результаті побудови прогностичної моделі встановлено, що на ймовірність розвитку проліферативної ДР у хворих на ЦД 2-го типу протягом 4 років впливають: вміст ММП-9 у ВОР, стадія ДР на початку спостереження та тривалість ЦД 2-го типу. За вмісту ММП-9 $\geq 100$ нг/мл, тривалості ЦД 2-го типу понад 10 років і відсутності ознак ДР на початку спостереження ймовірність розвитку проліферативної ДР становила $85.9 \%$.

Ключові слова: система протеолізу; металопротеїназа-9; тканинний інгібітор матриксної металопротеїнази 1; внутрішньоочна рідина; діабетична ретинопатія.

\footnotetext{
${ }^{1}$ Украйнський науково-практичний центр ендокринної хірургії, трансплантації ендокринних органів $і$ тканин МОЗ Украӥни, Київ; ${ }^{2}$ Донецький національний медичний університет ім. М. Горького, Красний Лиман; ${ }^{3}$ Начіональна медична академія післядипломної освіти

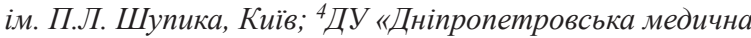
академія МОЗ України», Дніпро
}

\section{С.В. Зяблицев ${ }^{1}$, А.В. Коробова ${ }^{2}$, О.В. Петренко ${ }^{3}$, В.Н. Сердюк ${ }^{4}$, С.Ю. Могилевский ${ }^{3}$ \\ РОЛЬ МАТРИКСНОЙ \\ МЕТАЛЛОПРОТЕИНАЗЫ 9 И ЕЕ ТКАНЕВОГО ИНГИБИТОРА 1 В РАЗВИТИИ И ПРОГНОЗИРОВАНИИ ДИАБЕТИЧЕСКОЙ РЕТИНОПАТИИ}

В статье приведены результаты исследований нарушений в системе протеолиза у больных сахарным диабетом (СД) 2-го типа и диабетической ретинопатией (ДР). Определяли содержание матриксной металлопротеиназы-9 (ММП-9) и ее тканевого ингибитора 1 (ТИМП-1) в крови и внутриглазной жидкости (ВГЖ) у больных СД 2-го типа иммуноферментным методом. Установлены изменения в системе протеолиза у больных ДР и СД 2-го типа, которые заключались в повышении содержания ММП-9 и ТИМП-1 в крови и ВГЖ как при отсутствии признаков ДР, так и при любой ее стадии в сравнении с этими показателями у больных без диабета. Установлено, что содержание ММП-9 во ВГЖ и давность СД 2-го типа влияют на вероятность развития диабетического макулярного отека. При содержании ММП-9 $\geq 105$ нг/ мл и длительности СД 2-го типа $\geq 10$ лет вероятность развития отека составляет $100 \%$. На вероятность развития пролиферативной ДР у больных СД 2-го типа в течение 4 лет наблюдения влияют: содержание ММП-9 во ВГЖ, стадия ДР в начале наблюдения и длительность СД 2-го типа. При содержании ММП-9 $\geq 100$ нг/мл, длительности СД 2-го типа $\geq 10$ лет и отсутствии признаков ДР в начале наблюдения вероятность развития пролиферативной формы составляет $85.9 \%$.

Ключевые слова: система протеолиза; металлопротеиназа-9; тканевой ингибитор матриксной металлопротеиназы-1; внутриглазная жидкость; диабетическая ретинопатия.

${ }^{1}$ Украинский научно-практический цеентр эндокринной хирургии, трансплантации эндокринных органов и тканей МЗ Украины, Киев; ${ }^{2}$ Донеиякий нацииональный медииинский университет им. М. Горького, Красный Лиман; ${ }^{3}$ Национальная медицинская академия последипломного образования им. П.Л. Шупика, Киев; ${ }^{4}$ ГУ «Днепропетровская медииинская академия МОЗ Украины», Днепр

\section{REFERENCES}

1. Evrosimovska B, Velickovski B, Dimova C, VeleskaStefkovska D. Matrix metalloproteinases (with accent to collagenases). J Cell Anim Biol. 2011; 5(7). 113-20.

2. Raffetto JD, Khalil RA. Matrix Metalloproteinases and their inhibitors in vascular remodeling and vascular disease. Biochem Pharmacol. 2008; 75(2): 346-59. doi: 10.1016/j.bcp.2007.07.004.

3. Nagase H, Woessner JF. Matrix metalloproteinases. J Biol Chem. 1999; 274: 21491-4. doi: 10.1074/ jbc.274.31.21491.

4. Giebel SJ, Menicucci G, McGuire PG. Matrix metalloproteinases in early diabetic retinopathy and their role in alteration of the blood-retinal barrier. Lab Invest. 2005; 85(5): 597-607. doi: 10.1038/labinvest.3700251.

5. Malemud CJ. Matrix metalloproteinases (MMPs) in health and disease: an overview. Front Biosc. 2006; 11. 1696-701.

6. Rogowicz A, Zozulińska D, Wierusz-Wysocka B. Role of matrix metalloproteinases in the development of vascular complications of diabetes mellitus - clinical implications. 
Pol Arch Med Wewn. 2007; 117 (3): 1-7.

7. Bhatt LK, Addepalli V. Attenuation of diabetic retinopathy by enhanced inhibition of MMP-2 and MMP-9 using aspirin and minocycline in streptozotocin-diabetic rats. Amer J Translat Res. 2010; 2(2): 181-9.

8. Kowluru RA, Mohammad G, dos Santos JM, Zhong Q. Abrogation of MMP-9 gene protects against the development of retinopathy in diabetic mice by preventing mitochondrial damage. Diabetes. 2011; 60(11): 3023-33. doi:10.2337/db11-0816.

9. Derosa G, D’Angelo A, Tinelli C, Devangelio E, Consoli A, Miccoli R, Penno G, Del Prato S, Paniga S, Cicero AFG. Evaluation of metalloproteinase 2 and 9 levels and their inhibitors in diabetic and healthy subjects. Diabet Metabol. 2007; 33(2): 129-34. doi: 10.1016/j. diabet.2006.11.008.

10. Rangasamy S, McGuire PG, Das A. Diabetic retinopathy and inflammation: novel therapeutic targets. Middle East Afr J Ophthalmol. 2012; 19 (1): 52-9.

11. Kowluru RA. Role of Matrix Metalloproteinase-9 in the development of diabetic retinopathy and its regulation by H-Ras. Invest Ophthalmol Visual Sci. 2010; 51(8): 4320-26. doi: 10.1167/iovs.09-4851.

12. Zheng Y, He M, Congdon N. The worldwide epidemic of diabetic retinopathy. Ind J Ophthalmol. 2012; 60(5): 428-31. doi: 10.4103/0301-4738.100542.

13. El-Azab MF, Mysona BA, El-Remessy AB. Statins for prevention of diabetic-related blindness: a new treatment option? Exp Rev Ophthalmol. 2011; 6(3): 269-72. doi: 10.1586/eop.11.36.

14. Shaw JE, Sicree RA, Zimmet PZ. Global estimates of the prevalence of diabetes for 2010 and 2030. Diabetes Res Clin Pract. 2010; 87(1): 4-14. doi: http://dx.doi. org/10.1016/j.diabres.2009.10.007.

15. International Diabetes Federation. IDF Diabetes Atlas, 7 ed. Brussels, Belgium: International Diabetes Federation, 2015.

16. Wilkinson-Berka JL. Angiotensin and diabetic retinopathy. Int J Biochem Cell Biol. 2006; 38: 752-65. doi:10.1016/j. biocel.2005.08.002.
17. Cheung N, Mitchell P, Wong TY. Diabetic retinopath. Lancet. 2010; 376(9735): 124-36. doi: 10.1016/S01406736(09)62124-3.

18. Tronko MD, Sokolova LK, Vlasenko NV, Kostukevich AA., 2015. Achieving the goals in treatment of patients with diabetes mellitus in Ukraine. Results Diabetes Management Practices Study (IDMPS). Endokrynologia. 20(4): 658-68. [Ukrainian].

19. Kowluru RA, Zhong Q, Santos JM. Matrix metalloproteinases in diabetic retinopathy: potential role of MMP9. Exp Opin Invest Drugs. 2012; 21(6): 797-805. doi: 10.1517/13543784.2012.681043.

20. Demirel S, Argo C, Agarwal A, Parriott J, Sepah YJ, Do DV, Nguyen QD. Updates on the clinical trials in diabetic macular edema. Middle East Afr J Ophthalmol. 2016; 23(1): 3-12. http://doi.org/10.4103/0974-9233.172293.

21. Global Diabetic Retinopathy Project Group. Proposed international clinical diabetic retinopathy and diabetic macular edema disease severity scales. Ophthalmology. 2003; 110(9): 1677-82. doi http://dx.doi.org/10.1016/ S0161-6420(03)00475-5.

22. Tayebjee MH, Lim HS, Macfadyen RJ. Matrix metalloproteinase- 9 and tissue inhibitor of metalloproteinase-1 and -2 in type 2 diabetes. Diabetes Care. 2004; 27(8): 2049-51.

23. Heo $\mathrm{SH}$, Cho $\mathrm{CH}$, Kim HO, Jo YH, Yoon KS, Lee JH, Park JC, Park KC, Ahn TB, Chung KC, Yoon SS, Chang DI. Plaque rupture is a determinant of vascular events in carotid artery atherosclerotic disease: involvement of Matrix Metalloproteinases 2 and 9. J Clin Neurol. 2011; 7(2): 69-76. http://dx.doi.org/10.3988/jcn.2011.7.2.69.

24. Beránek M, Kolar P, Tschoplova S, Kankova K, Vasku A. Genetic variations and plasma levels of gelatinase A (matrix metalloproteinase-2) and gelatinase B (matrix metalloproteinase-9) in proliferative diabetic retinopathy. Mol Vis. 2008; 14: 1114-21.

25. Abu El-Asrar AM, Mohammad G, Nawaz MI et al. Relationship between vitreous levels of Matrix Metalloproteinases and Vascular Endothelial Growth Factor in proliferative diabetic retinopathy. PLoS One. 2013; 8(12): e85857. doi: 10.1371/journal.pone.0085857.

Received 17.05.2016 